\section{Management of natural systems}

Genetics of Forest Ecosystems. By Klaus Stern and Laurence Roche. Pp. 330. (Chapman and Hall: London; Springer: Berlin and New York, 1974.) $£ 12.25$.

IN his preface Roche states that forest ecosystems are a rich source of information on ecological genetics but that published evidence has not yet significantly penetrated the botanical literature. Little exception could be taken to the first part of that statement, and the book, itself a rich source of information, goes some way towards correcting the imbalance mentioned in the latter part. But according to the introductory remarks by Stern the book aims to be more than a catalogue of information on stable and transitory forest ecosystems. Stern assumes that forest ecologists and breeders have been more concerned than agronomists with the inner mechanisms of ecosystems and that only by knowing these mechanisms could the former group hope to improve the economics of forestry. Accepting that this is true and that ecologists and breeders significantly affect forestry praotice, then discussion of the state of man's knowledge of these mechanisms, which form an important part of the book, is a valuable contribution to the intelligent management of the world's forest resources.

The main subjects-ecological niches, adaptations, genetic systems, adaptive strategies and forest ecosystems-are approached in a similar manner throughout. First, formal definitions are stated and discussed and that is followed by a consideration of mathematical concepts and their limitations and applicability. Finally, examples are given, mainly from the forest ecosystem, to illustrate and complement the previous discussions. The use of the concepts of systems theory, games strategy and cybernetics will provide difficult reading to the uninitiated. Such difficulties are compounded by the odd misprint, the occasional grammatical peculiarities, and a style of writing which may well be a consequence of translation from the original German.

In a book of this scope it is always possible to find something to criticise but I must say that I thought that the chapter on genetic systems of forest trees species placed undue emphasis on selfing, whereas the reader was referred elsewhere for information on other aspects. And there is much space devoted to Fowler's work on Pinus resinosa but his conclusions are reponted erroneously in the text. On the other hand, there is much of which I approved, such as the discussion of the tropical ecosystem, which emphasises and contrasts the ideas of Federov and Ashton.

The final chapter, contributed by Roche, is a review of man's effect on the ecosystem. It is proposed in the introduction that this chapter could well have been placed in a separate book. Had it been placed at the beginning of this book, however, its contents would have encouraged those whose activities affect the forest ecosystem to read the following chapters.

Ian R. Brown

\section{Viral diseases}

Slow Virus Diseases. Edited by John Hotchin. Pp. xvii+372. (Karger AG: Basel, London and New York, 1974.) $£ 19.80 ; \$ 49.75$.

THE title of this book is misleading for the text is concerned mainly with persistent viral infections. 'Slow' infections constitute only a small and unrepresentative group. Seventy pages describe the arena virus group of which LCM virus is the prototype. In contrast, the 'slow' virus diseases are described less adequately. Thirty pages outline reasons for viral persistence, and examples of diseases of man and animals in which persistent virus is considered important in pathogenesis are written about with varying clarity by 27 specialists. All in all, the book is a useful introduction to a developing but not well-defined area of medicine.

John T. Stamp

\section{Plants beneath the rising Sun}

The Flora and Vegetation of Japan. Edited by M. Numata. Pp. X +294 . (Kodansha: Tokyo; Elsevier Scientific: London and New York, 1974.) Dfl80; $\$ 30.80$.

SinCE 1950, the Japanese have achieved an international reputation for the originality and importance of their contribution to quantitative studies in plant ecology. The analysis by Mcnsi and Saeki of the attenuation of solar radiation intercepted by herbaceous vegetation, the application by Hozumi ct allometric methods to the estimation of growth of forest stands, and the studies by Kira and his associates of intraspecific competition are all examples of work which has attracted world-wide attention. Recognition of the significance of this work has been facilitated by publication in English and German. In contrast, most of the literature on the vegetation of Japan has been published in Japanese so that it remains relatively inaccessible. Now a concise guide is available in English and it provides an excellent account of one of the most intensively studied and interesting vegetational regions of the world.

Modern Japan extends from the northern coast of Hokkaido (latitude $46^{\circ} \mathrm{N}$ ) to the southernmost of the Ryukyu islands which is almost on the Tropic of Cancer; a distance of over $3,000 \mathrm{~km}$ along the great archipelago which stretches from Kamchatka and the Kuril. Islands in the north to Formosa (Taiwan) and the Phillipines in the south. During the climatic vicissitudes of the Pleistocene, the continuity of the archipelago seems to have allowed much of the Eocene flora to survive by oscillating from north to south and back. Consequently, the flora of Japan is extraordinarily rich, with almost 4,000 vascular plants, including many endemics and relict species of the Arcto-Tertiary flora, and a great wealth of woody species.

Small areas of sub-tropical vegetation occur on the Ryukyu islands but the original vegetation on the main islands ranges from warm temperate forests, comprising largely evergreen broad-leaved species in Kyushu, Shikoku and southern Honshu, to cool temperate forests, characterised by beech (Fagus crenata) and representatives of several familiar temperate genera such as Acer and Prunus, in northern Honshu. Subarctic coniferous forests of Abies sachalinensis and Picea spp. are present on the mountains of Honshu and descend to sealevel in Hokkaido. This latitudinal zonation is accentuated by the warm Tsushima and Kuro-shio currents which originate in the tropics and have a large influence on the climate of the southern islands but which fail to reach Hokkaido.

Much of the land which would naturally carry forest has been modified greatly and is now occupied by grassland or vegetation dominated by Pteridium aquilinum. There is a wide variety of coastal vegetation and extensive regions of subalpine and alpine vegetation, in which a majority of the genera are those important in Europe. The final section is devoted to an account of the vegetation of active volcanoes and includes some remarkable illustrations of recent lava flows and pumice deposits now covered by forests.

The book provides a clear and fascinating account of Japanese vegetation and of the many geographical and ecological problems presented by its complexity and its considerable modification by man. It is well written, well balanced in its presentation and has numerous illustrations which are uniformly of high quality. 